\title{
グリーン関数の震源位置依存性と強震動生成域の配置が計算地震動に与える影響 SOURCE LOCATION DEPENDENCE ON GREEN'S FUNCTIONS AND THE EFFECTS OF THE ARRANGEMENT OF STRONG MOTION GENERATION AREA ON COMPUTED GROUND MOTIONS
}

\author{
寺島芳 洋*1, 福和 伸夫*2
}

\section{Yoshihiro TERASHIMA and Nobuo FUKUWA}

\begin{abstract}
We examined the method of setting the strong motion generation area (SMGA) based on visualization of the Green's function between the site and the source from the viewpoint of building response. Long-period ground motions in the Kanto urban area due to the inter-plate earthquake along the Sagami Trough was used as the subject. We found that the predicted wave which SMGAs were placed in predominant area of response spectrum and energy spectrum is larger and longer than the conventional prediction, and this predominant area depends on the building period, damping constant and the target city.
\end{abstract}

Keywords : Long-period ground motion, Strong motion generation area, Green's function, Megathrust earthquake along the Sagami Trough, the Kanto Basin 長周期地震動, 強震動生成域, グリーン関数, 相模トラフ, 関東平野

\section{1. はじめに}

南海トラフや相模トラフ沿いで発生が想定される海溝型地震につ いて，近年，地震動予測に用いられる震源モデルに多様性が考慮さ れるようになってきた。南海トラフについては過去の被害地震から 推定した震源モデルに基づく基本ケースに加えてその強震動生成域 （SMGA）の位置を変えた複数ケースが想定されており 1)，相模卜 ラフについても SMGA の配置や面積等のパラメータの多様性が考 慮されている2)。

建築構造物の設計用入力地震動の作成においても, 海溝型地震に 加えて活断層の地震について複数の断層や震源パラメータを考慮す ることが推奨されている ${ }^{3)}$ 。ただし, 活断層についてはその発生頻 度の低さと日本国内における活断層の数から過去の被害地震を根拠 として震源モデルを作成できるケースは稀である。このため SMGA については断層面の中心や震源域にバランスよく配置するなどして 複数ケースの震源モデルを作成し，その中で計画する建築構造物の 応答が大きくなるケースが採用される例えば4)

ただし実際には考え得る全断層や震源条件を網羅することは困難 であるため, 計画サイトに近い活断層や SMGA 配置を中心に検討 する場合が多い。構造物の周期が短く, 短周期の地震動が重要とな る場合にはこういった考え方でも良いが, 長周期地震動を考慮した 場合には, 必ずしも震源と計画サイトの近さが地震動の大きさに直 結せず，計画サイトに対する震源方位や震源深さも重要な因子であ ることが報告されており 5)-20), 上記の検討では十分ではない可能性 がある。

この問題を解決するためのアプローチとしては, 東京都心など高 層建物が集中する都市部のサイトについて検討すべき SMGA の配
置や断層を予め整理しておくことが考えられる。

ここで震源方位や位置の違いによる長周期地震動の変動に関する 既往研究を整理する。座間 5), 植竹 ${ }^{6)}$ ，湯沢・南雲 7) は関東平野にお ける長周期地震動の観測記録を分析し，その振幅と卓越周期が震源 位置に依存すること, Ishii ${ }^{8}$ は継続時間が変動することを確認した。 また，著者ら 9)は振幅や位相特性と震央距離の関係が震源方位に依 存することを確認した。

長周期地震動の震源方位や位置による変動の要因として, ある震 源方位では複数の伝播経路を辿った表面波が平野上で合流，集中し て, 振幅が大きくなることが指摘されており例えば 10)-13), これらの研 究では関東平野における過去の地震記録や数值シミュレーションに 基づく検討がなされている。また別の要因としては, 震源からサイ トに至るまでの付加体などの堆積物の影響が考えられる 14)-16)。これ らの研究 14)-16)では南海トラフ沿いの付加体が長周期地震動の振幅 や継続時間に影響を与えること, 山田他 $\left.{ }^{16}\right)$ は付加体に加え震源近傍 の堆積盆地構造も長周期地震動の変動に寄与することを指摘してい る。

これらの変動に寄与するパラメータとしては震源方位に加えて, 地下構造や震源深さ, 震源メカニズムが指摘されている 17)-20)。地下 構造の影響として, 平井・福和 ${ }^{17)}$ は円形盆地や楕円型盆地といった 単純な盆地モデルによる震源方位の影響を分析し，その不整形度合 いの重要性を指摘した。Petukhin et al. ${ }^{18)}$ は数值解析に基づき地殼 構造の有無で波動場を比較し, コンラッド不連続面による地震波の 反射が長周期地震動の変動に寄与寸ることを指摘した。また, 震源 の影響として, 著者ら ${ }^{199}$ は関東平野の地下構造モデルを用いて震源 深さに対する検討を実施し, 震源深さが浅いほど長周期地震動の変
·1 株竹中工務店 修士 (工学)

2 名古屋大学減災連携研究センター 工博
Takenaka Corporation, M.Eng.

Prof., Disaster Mitigation Research Center, Nagoya University, Dr.Eng. 
動が大きいことを指摘した。向井ら ${ }^{20}$ は 2004 年新潟県中越地震や 2011 年福島県浜通りの地震を対象に震源モデルの走向を漸増させ た検討を実施し，これらの地震ではある走向になると平野内でレイ リー波が強く励起され, 関東平野における地震動の振幅が大きくな ることを指摘した。

このように既往の研究において, 長周期地震動の変動の要因や変 動に寄与するパラメータについてはわかってきているものの, 実際 に SMGA を配置するためには震源域内でのグリーン関数の分布を 可視化し，建築構造物に影響が大きい領域を明らかにすることが課 題となっている。Petukhin et al. ${ }^{18)}$ は, 南海トラフ沿いの地震を対 象に大阪市此花区での長周期地震動を計算し, その地動最大速度を 震源域にプロットし可視化した。

本研究では，サイトと震源域を結ぶグリーン関数を建物応答の指 標で可視化して SMGA を配置する方法とその効果を検討すること を目的に，首都圈で発生が危惧される相模トラフ沿いのプレート境 界地震を題材として数值シミュレーションを実施した。検討では, 上述した Petukhin et al. ${ }^{18)}$ における地動最大速度を震源域にプロッ 卜寸る可視化を建築構造物の応答に拡張して, 建物周期と減衰定数 を仮定した最大応答值や継続時間の指標を用いてグリーン関数の分 布を可視化した。次に可視化したグリーン関数の空間分布に基づき SMGA を配置した場合と既往の SMGA 配置による波形合成の結果 を比較して，その効果を確認した。また検討に併せて，グリーン関 数が大きくなる震源領域については, そこから生ずる地震波の伝播 経路を推定することで空間分布の解釈が可能か検討した。

\section{2. 方法}

まず， 3 次元有限差分法による数值解析を実施し，震源域におけ る震源 - サイトを結ぶグリーン関数の空間分布を調べた。建築構造 物の応答に着目して, グリーン関数から応答スペクトルとエネルギ 一スペクトルを計算し，それらをプロットすることにした。次に， 既往の震源モデルに基づき地震波合成した結果と，本研究で得られ たグリーン関数が大きくなる領域に SMGA を配置した地震波合成 の結果を比較した。また,グリーン関数が大きくなる領域について, 有限差分法で計算した波動場からセンブランス解析を用いて伝播経 路を調べ，グリーン関数との関係を分析した。以下に具体的な解析 条件等を示す。

\section{2-1. 検討の対象とする震源域とサイト}

広域な想定震源域を有する相模卜ラフ沿いのプレート境界地震と 関東地方の都市部における長周期地震動を対象とした。本地震につ いては，関東都市部への影響の大きさから行政機関等による地震動 予測が活発に実施されている 2),21),22)。図 1 にこれらの地震動予測で 使用された震源モデルの SMGA を示す。東京都と中央防災会議の 震源モデル 21), 22) は過去の地震による地震動分布から決められてい るのに対し, 地震調查研究推進本部の長周期地震動予測地図 2016 年試作版で策定された震源モデル 2)では多様性が考慮されており，

SMGA の配置だけでも 20 ケース以上が想定されている。

本研究では地下構造モデルと既往の震源モデルを参考に, 図 2 に 示寸震源領域を解析対象とした。具体的には, 全国一次地下構造モ デル 23)における北米プレートとフィリピン海プレートの境界を抽 出した。加えて, 中央防災会議の震源モデル設定 22)では, 深さ 53

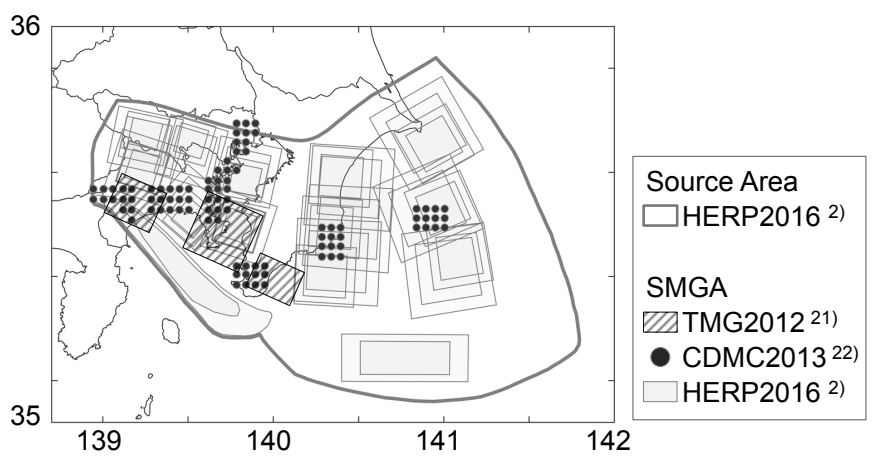

Fig.1 Source models of the Sagami Trough earthquake

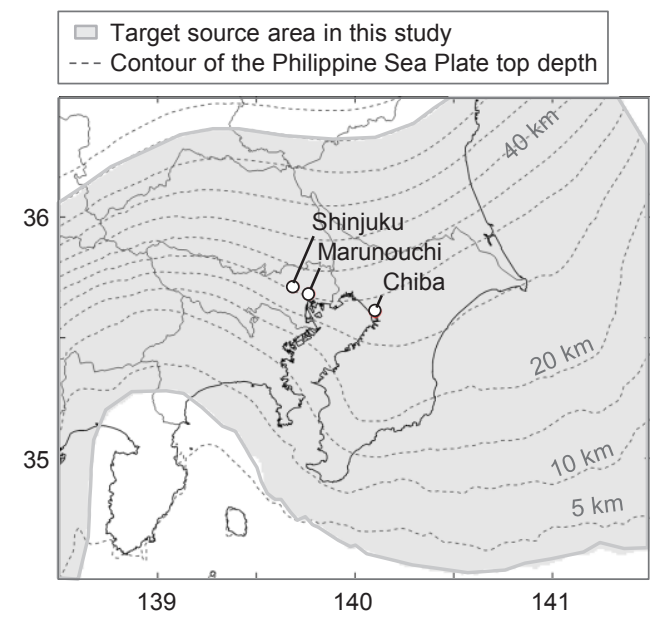

Fig.2 Target source area and sites in this study

$\mathrm{km}$ 以深において上記領域でのプレート境界地震が発生していない ことを考慮して震源モデルの最深部を $53 \mathrm{~km}$ としており, これを網 羅するようにフィリピン海プレート上面深度が $55 \mathrm{~km}$ 以浅である 領域を抽出した。また, 要素震源の走向や傾斜はフィリピン海プレ 一トの形状から算出した。す心゙り角は長周期地震動予測地図 2016 年試作版 2)を参考に $140^{\circ}$ に設定した結果を中心に検討を行い，こ れに加えて震源メカニズムの違いによる影響を把握するためにす心゙ り角の違いによる結果の変化を確認した。

要素震源の地震モーメントは $1 \mathrm{Nm}$, 震源時間関数は三角型（ラ イズタイム 2 秒）とした。本論文で議論するポイントは震源位置に よる地震動の変動であり, 同一周期帯での地震動の震源位置による 変化に注目するため, 地震モーメントや震源時間関数の設定が結果 に与える影響はほとんどないと考えられる。

有限差分法の解析では, 図 2 の震源域を $2 \mathrm{~km}$ 四方のグリッドで 分割して要素震源を配置し，それらとサイトを結ぶグリーン関数を 計算した。震源域を分割したところ, 要素震源の数は 18,533 個とな った。図 2 に検討に用いたサイトを示す。本研究で対象とした地点 は新宿サイト $(35.7107 \mathrm{~N}, 139.6859 \mathrm{E})$ と丸の内サイト $(35.6816 \mathrm{~N}$, $139.7654 \mathrm{E})$ ，千葉サイト $(35.6082 \mathrm{~N}, 140.1022 \mathrm{E})$ である。新宿サ イトと丸の内サイトは $10 \mathrm{~km}$ 弱, 新宿サイトと千葉サイトは $40 \mathrm{~km}$ 弱離れている。いずれのサイトも超高層建物が数多く立地している。

\section{2-2. 差分法を用いた数值解析の条件}

グリーン関数の計算には 3 次元地盤モデルを使用し，有限差分法 24)による解析を実施した。地盤モデルとして全国一次地下構造モデ ル 23)を用いた。著者らの既報9でも本モデルを検討に使用しており， 
関東周辺の地震について長周期成分の距離減衰性状が観測と数值解 析で対応することを確認している。

有限差分法による解析では, グリーン関数の相反定理を活用して 計算コストを削減した ${ }^{17)}$ 。これは計算する要素地震が数万点あり, 相反定理を活用しない方法では 1 つのサイトにつき膨大な回数の解 析を実施しなければならないためである。相反定理を活用すること で， 1 つのサイトにつき水平 2 成分と上下 1 成分の加振による 3 回 の解析で必要なグリーン関数を計算できた。なお, 後述するセンブ ランス解析では, 対象サイトのみならず伝播経路上の解析波形が必 要であるため, そちらで使用する波動場は相反定理を使わない通常 の方法で計算した。また, 有限差分法の解析条件として, 空間を 200 $\mathrm{m}$ 刻み, 時間を $0.01 \mathrm{~s}$ 刻みで離散化した。本解析による参照可能な 最小周期は $2.4 \mathrm{~s}$ であり, 全ての計算波形には $0.05 \sim 0.4 \mathrm{~Hz}$ のバ ンドパスフィルタをかけている。なお, 解析領域の端部は無反射境 界 25) と吸収境界 26) とした。非弾性減衰の参照周期は $2 \mathrm{~s}$ とした。

\section{2-3. センブランス解析の条件}

グリーン関数が大きくなる震源領域を特定したのち, そこから生 ずる波動の伝播経路を推定して, グリーン関数と伝播経路の関係を 分析する。本論では有限差分法の結果に対して, センブランス解析 27)を実施し，その伝播経路を推定する。

センブランス解析では式(1)のセンブランス值 $S_{0}$ が最大となる ような伝播速度と伝播方位をグリッドサーチにより推定した。ここ で式(1)について, $u$ は速度波形, $t$ は時刻, $i$ と $j$ はそれぞれ地点と 単一時間空内の時刻のサフィックスを示す。 $\Delta t_{i 0}$ は基準地点と $i$ 地 点との走時差であり, 伝播方位に沿った基準地点と $i$ 地点との水平 距離を伝播速度で除して求まる。また, グリッドサーチの条件とし て, 伝播速度は $0.4 \sim 4.0 \mathrm{~km} / \mathrm{s}$ を $0.1 \mathrm{~km} / \mathrm{s}$ 刻みで, 伝播方位は計算 地点と震央の方位角 $\pm 60^{\circ}$ を $3^{\circ}$ 刻みで探索した。

$$
S_{0}(t)=\frac{1}{N} \frac{\sum_{j}\left(\sum_{i} u\left(t_{j}+\Delta t_{i 0}\right)\right)^{2}}{\sum_{j} \sum_{i} u^{2}\left(t_{j}+\Delta t_{i 0}\right)}
$$

\section{3. 結果}

\section{3-1. 想定震源域におけるグリーン関数の空間分布}

サイトと要素震源を結ぶグリーン関数について, 震源域における 空間分布を調べた。まず, 図 3 に新宿サイトとそこから震央距離 50 $\mathrm{km}$ の同心円線下にある震源に関するグリーン関数の時刻歴波形と スペクトルを示し，方位による特徵を概観する。各要素震源は図 2 のフィリピン海プレート上面深度と対応しており, サイトとの震源 距離が震源によって最大 $20 \mathrm{~km}$ 程度異なる。ここでは震源方位によ る時刻歴波形やスペクトル形状と振幅を比較することが目的である ため, 震源距離の補正はしないこととした。なお, 震源メカニズム の設定等の計算条件は 2 章に基づき, すべり角については前述の $140^{\circ}$ とそれに直交する $50^{\circ}$ の結果を示した。図 3 には, 速度波形 に加えて, 速度応答スペクトル $(h=5 \%)$ とその全方位の平均值お よび標準偏差を示す。

二種類のすべり角に共通した特徴として速度波形およびスペクト ルともに南方から西方の震源で振幅が大きくかつ継続時間が長い, また北方から東方の震源では振幅が非常に小さい。これらは Radial 成分と Transverse 成分に共通した性状である。振幅が大きな南方 から西方の震源に限定しても波形に特徴が見られ, 具体的には南西
方向の震源における Transverse 成分では後続波部振幅が大きく, それ以外の震源では長い時間にわたって振幅が大きい結果となった。

図 4 に要素震源のすべり角を $140^{\circ}$ と設定した場合のグリーン関 数について, 震源域全体における分布を示す。速度応答スペクトル $S_{V}$ とエネルギースペクトル $V_{E}$ をプロットした。

図 4(a)に，新宿サイトに関するグリーン関数の空間分布を示す。 建物周期と減衰定数による違いを見るために減衰定数 $5 \%$ を仮定し た周期 $3-5$ 秒の平均值と減衰定数 $2 \%$ 仮定した周期 $5-7$ 秒の平 均值を示す。前者は一般的な超高層制振建物を，後者は特に周期が 長い超高層建物を想定した。振動成分については限定せず，全方位 の最大值である RotD10028)を用いた。また，図には各地の標高から 読み取った関東平野西端の山地 - 平野境界を示している。

図 4(a)において振幅の大きな領域を破線で示す。震源距離が近く なる新宿直下の領域に加えて, 南西から南にかけて関東平野端部に 沿った領域で振幅が大きくなる。 $S_{V}$ と $V_{E}$ の特徵は対応しているが, $S_{V}$ ではサイトに直下の破線部領域の振幅が相対的に大きく, $V_{E}$ で は遠方の破線部領域の振幅が目立つ結果となった。

また，建物周期や減衰定数によってグリーン関数が卓越する震源 位置は異なることがわかる。図 4(a)における異なる建物周期と減衰 定数の空間分布を比較すると, 振幅が卓越する方位や位置は概齐対 応するが，その位置は完全には一致しない。

要素震源のメカニズムがグリーン関数の空間分布に与える影響を 確認するために, 要素震源のすべり角を $0^{\circ}$ から $170^{\circ}$ まで $10^{\circ}$ 刻 みで設定した 18 ケースの数值解析結果から, 要素震源ごとに最大 值を抽出した。図 5 に最大值の空間分布を示す。大きな傾向として は，すべり角を $140^{\circ}$ とした図 4 と類似する特徵が見られた。具体 的には，新宿サイト，丸の内サイトでは震源距離が近くなる直下の 領域や南西から南にかけた関東平野端部に沿った領域で振幅が大き く, 千葉サイトでは南方の領域で振幅が大きい。ただし, 種々のす べり角の計算結果が含まれる図 5 の方が, 振幅が大きな領域が広い。 これはす心゙り角が変化することで振幅が大きくなる領域が変化する ことによる。

次にサイト毎の空間分布の特徵を調べるために, 図 4(b) (c) と図 5(b)(c)に丸の内サイトと千葉サイトに関するグリーン関数の空間分 布を示す。応答スペクトルは減衰定数 $5 \%$ を仮定して計算し, 周期 $3-5$ 秒の平均值をプロットした。

ともに東京都心である新宿サイトと丸の内サイトの間は $10 \mathrm{~km}$ 程度の距離であり，振幅が大きな領域は類似しているが，その空間 分布の細部には違いが見られる。具体的には, サイトの南方から西 方にかけて振幅が卓越することは共通しているが，それらの大小関 係に違いが見られる。丸の内サイトでは南方の震源よりも南西から 西方における震源の振幅が明らかに大きい。

また，千葉サイトの空間分布には他 2 サイトとは大きく異なる特 徵がある。新宿サイトと丸の内サイトで各サイト直下の震源よりも 振幅が大きい関東平野の端部に沿った領域での千葉サイトの振幅は 小さい。一方, 千葉サイトのエネルギースペクトルV $V_{E}$ において, 図 中に破線で示すサイト南方のフィリピン海プレート上面深度が浅い 領域で振幅が卓越している。なお, サイト直下で振幅が卓越する点 は他 2 サイトと共通した性状である。

図 6 には, サイト間の差異を明確するために, 各サイトの空間 

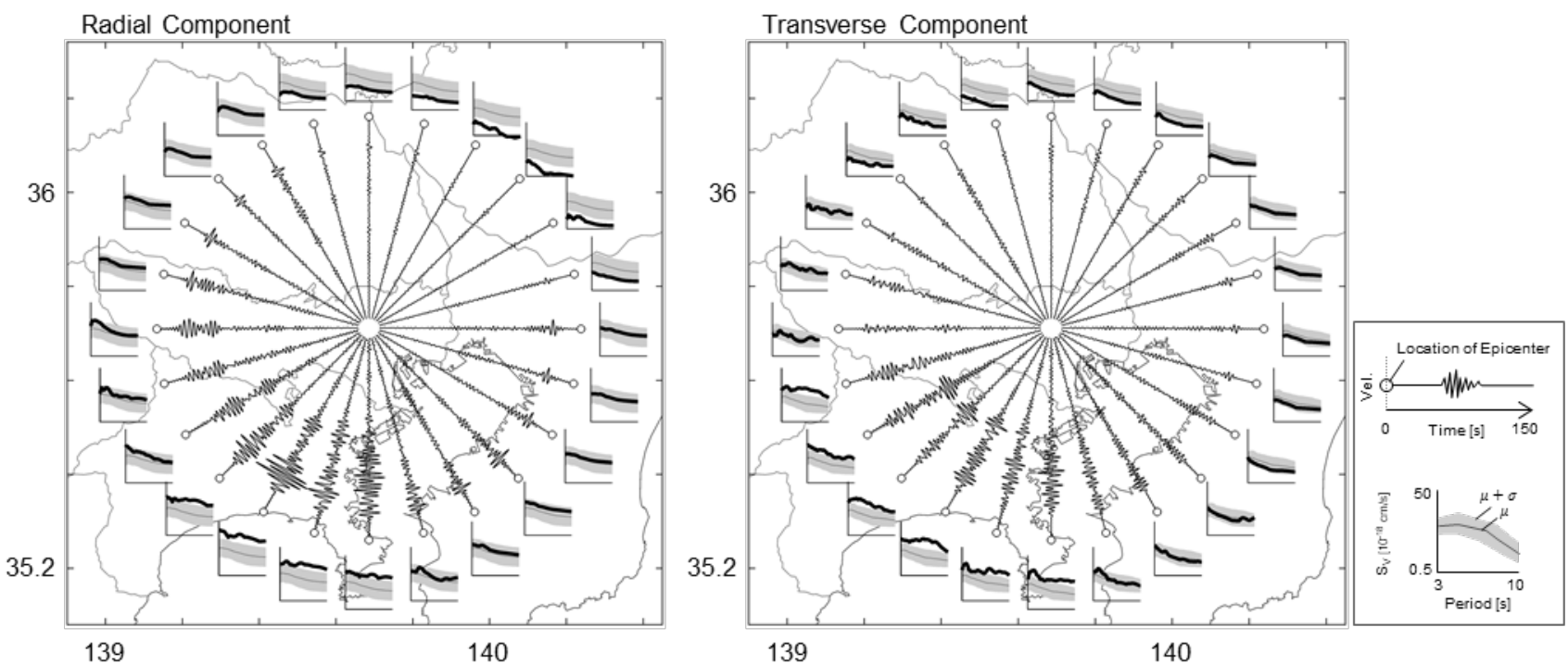

(a) rake $=140$ [deg.]
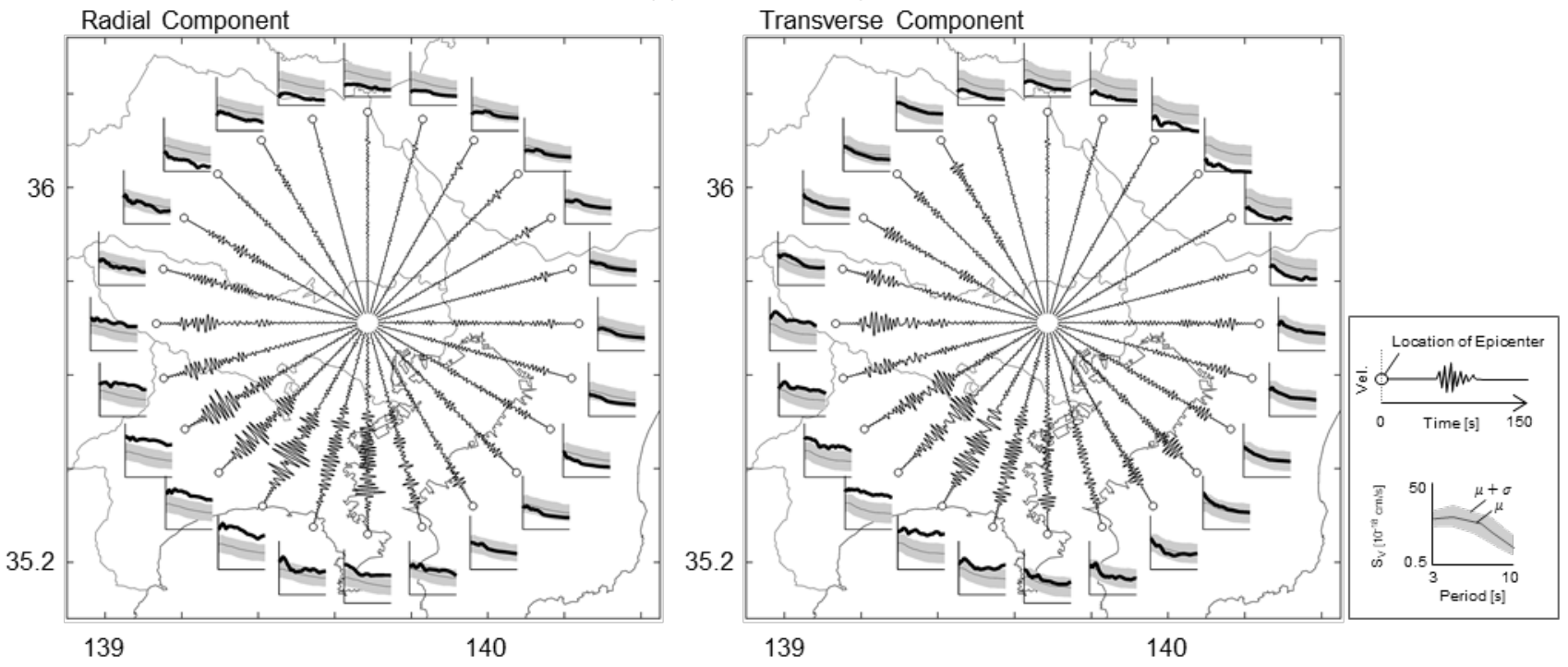

(b) rake $=50$ [deg.]

Fig.3 The Green's function at the epicenter $50 \mathrm{~km}$ away from the Shinjuku site
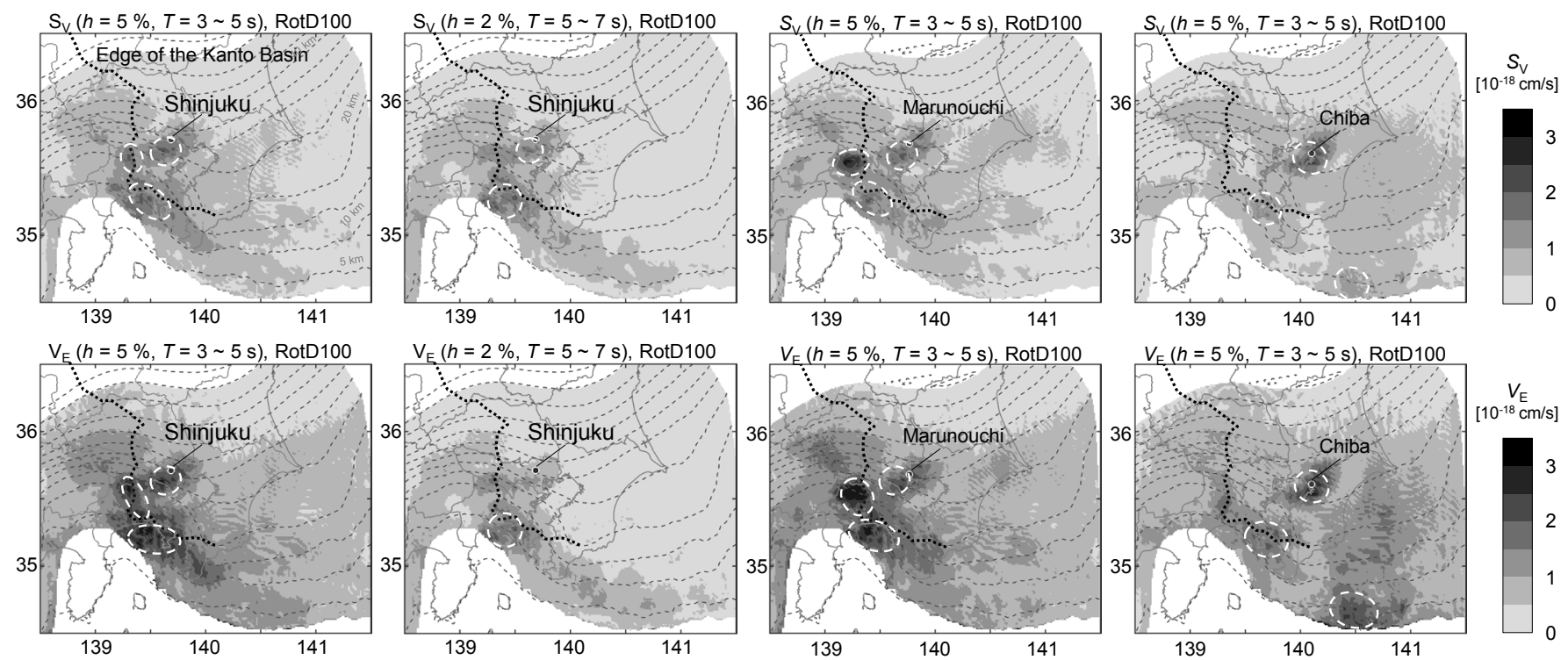

(a) Shinjuku site

(b) Marunouchi site

(c) Chiba site

Fig.4 Distribution of the Green's function ( rake $=140$ [deg.] ) in the source area 

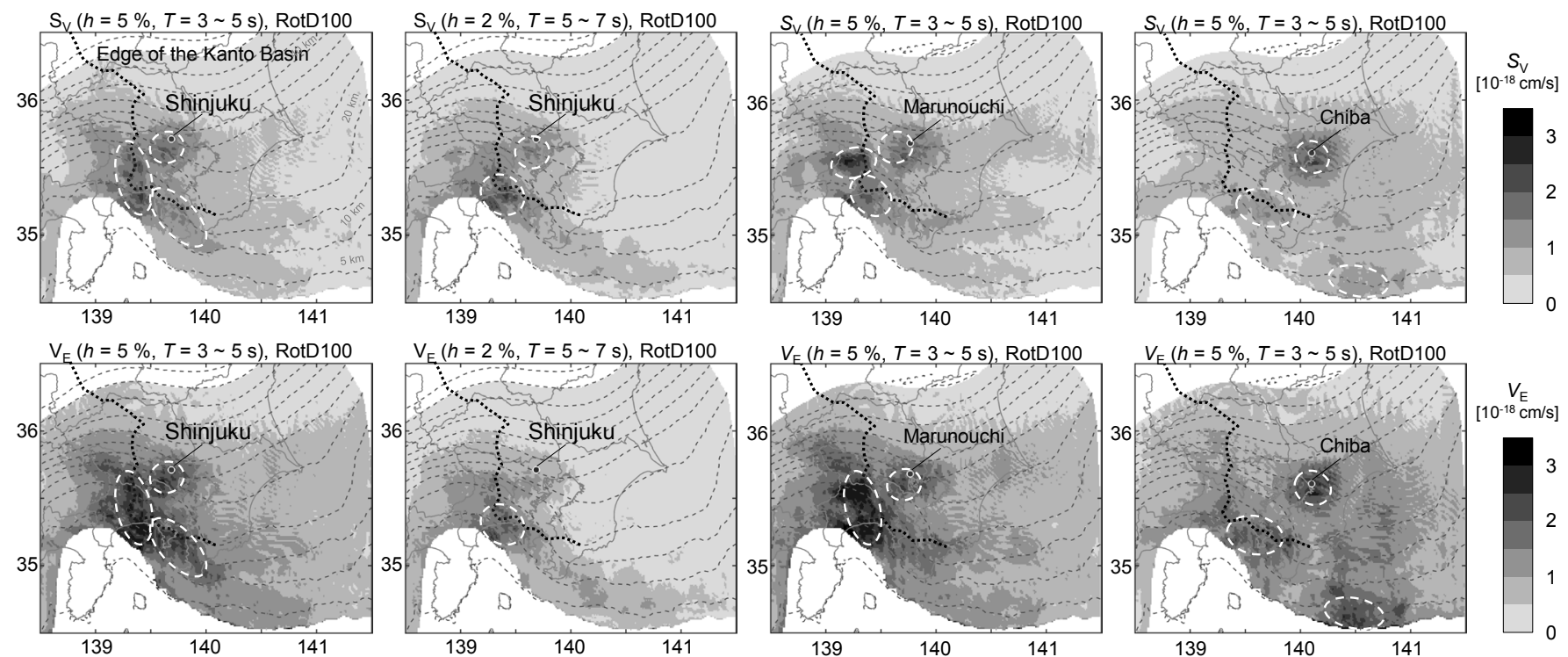

(a) Shinjuku site

(b) Marunouchi site

(c) Chiba site

Fig.5 Distribution of the Green's function ( Maximum value in the case of rake 0 to 170 degree ) in the source area

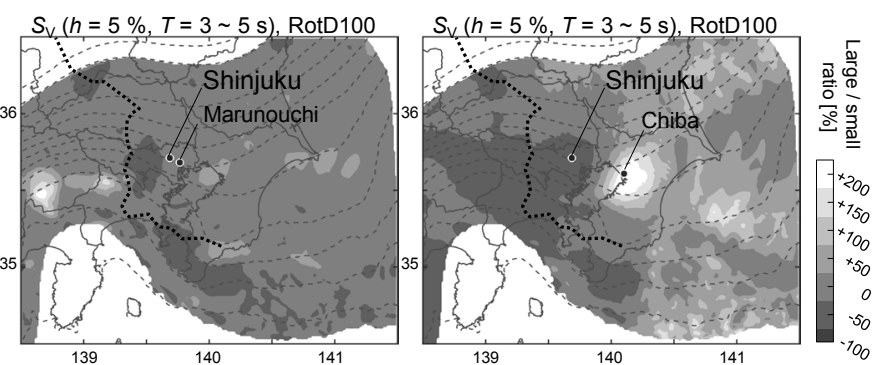

Fig.6 Difference between Shinjuku site and other sites

分布を新宿サイトの值で除して 100\%を引いた新宿サイトを基準と した大小割合を示寸。図 6 の計算には図 5 に示した空間分布のデ ータを使用している。

図 6 には，図 4 と図 5 に見られた新宿サイトと丸の内サイト，千 葉サイトの関係と対応する特徴が見られ，さらには千葉サイトと新 宿サイトの差異が丸の内サイトと新宿サイトの差異よりも大きいこ とがわかる。具体的には，丸の内サイトと新宿サイトの振幅は概敞 土25\%の大小関係にあるが，千葉サイトでは倍半分の関係にある領 域が広い。

\section{3-2. 強震動生成域の配置による地震動強さの変化}

前節ではサイトと各要素震源のグリーン関数を計算し, 震源域に おける分布を示した。その結果, 東京都心については南西から南方 の関東平野端部に沿った領域においてグリーン関数の振幅が大きく なることがわかった。本節では, 実際の設計用入力地震動作成と同 様に震源モデルを仮定し, SMGA や破壊伝播性状を考慮して波形合 成を実施した。既往の震源モデルをベースとして, その SMGA の位 置を移動させた場合の合成波形を計算し，元の波形と比較して SMGA 配置の影響を調べた。

図 7 に設定した SMGA の配置を示す。SMGA 配置の影響に着目 するために, 背景領域は考慮せず波形合成を実施した。地震調查研 究推進本部による長周期地震動予測地図 2016 年試作版で策定され た震源モデル 2)のうち, 元禄関東地震を対象とした $\mathrm{G} 1$ タイプの $\mathrm{Q} 3$ ケースをベースとして, アスペリティ 1 と 2 の位置をグリーン関数
の振幅が大きい領域へ移動させた。本研究で設定した SMGA と比 較して，その元となった Q3 ケースは新宿サイトとの距離が近いた め, 均質地盤の場合には Q 3 ケースの計算地震動の方が大きくなる。 図 7 には新宿サイトにおける速度応答スペクトル $(h=5 \%, T=$ 3 5s）の空間分布（同図 4(a)左上）を併せて示した。

表 1 に各 SMGA の震源諸元を示す。各要素震源の震源メカニズ ムとしては，2-1 節と同様にフィリピン海プレートの形状から算出 した走向と傾斜を用い，すべり角については $140^{\circ}$ を仮定した。破 壊開始点は図中星印とし，破壊伝播速度 $V_{R}$ は $2.7 \mathrm{~km} / \mathrm{s}$ とした。ま た，震源時間関数には中村・宮武の式 29)を用いた。

図 8 に新宿地点における波形合成結果を示寸。地震調查研究推進 本部の SMGA で計算した波形と比較すると，時刻 100 秒未満に違 いが見られ，本論の計算結果の方が大振幅かつ振幅が大きい時間が 長い。すなわち, グリーン関数の $S_{V}$ と $V_{E}$ が大きくなる領域に SMGA を配置することにより，波形合成結果が大きくなることがわ かった。また，応答スペクトルを見ると広い周期で本論の結果が 2

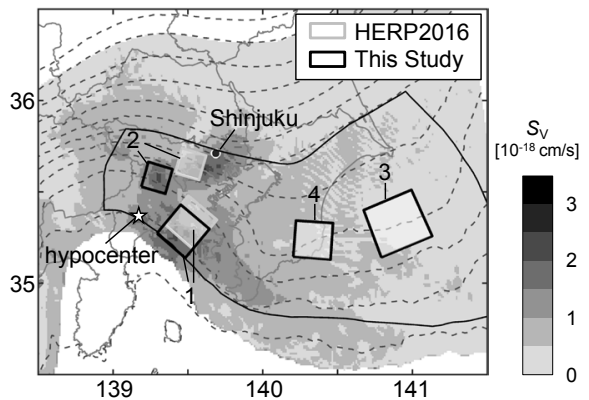

Fig.7 SMGA arrangements of HERP2016 ${ }^{2}$ and this study

Table1 Source parameters for each SMGA

\begin{tabular}{|c|c|c|c|c|}
\hline No. & 1 & 2 & 3 & 4 \\
\hline Seismic Moment $\left[10^{19} \mathrm{Nm}\right]$ & 20.9 & 6.39 & 51.6 & 18.7 \\
\hline Rise time [s] & 4.34 & 2.93 & 5.89 & 4.18 \\
\hline Slip [m] & 9.2 & 6.2 & 12.4 & 8.9 \\
\hline Area $\left[\mathrm{km}^{2}\right]$ & 550 & 250 & 1010 & 510 \\
\hline Stress drop [MPa] & 29.7 & 29.7 & 29.8 & 29.8 \\
\hline
\end{tabular}



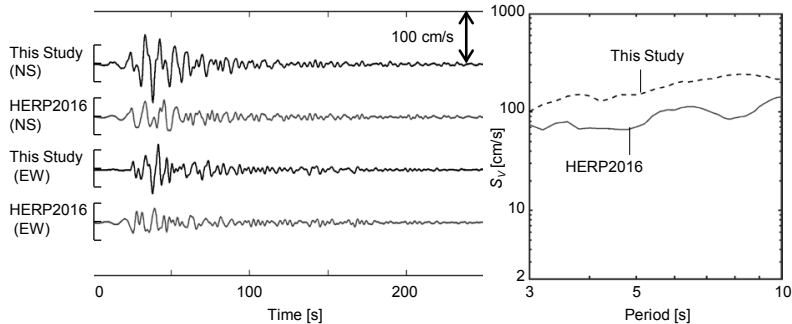

Fig.8 Waveform synthesis result at Shinjuku site

倍程度大きくなった。

\section{3-3. グリーン関数と伝播経路について}

3-1 節で, 東京都心についてグリーン関数の振幅が大きかったサ イト南西から南方の関東平野端部に沿った領域において, 有限差分 法により計算した波動場に対してセンブランス解析を実施し, 当該 領域から生じた地震波が辿る伝播経路を調べた。なお，震源と地盤 モデル, 差分法の解析条件などは $2-1$ 節に示した条件と同様とし, すべり角は $140^{\circ}$ を仮定した。

図 9 にセンブランス解析の対象とした震源と領域を示す。図 9 に は新宿サイトにおける速度応答スペクトル $(h=5 \%, T=3 \sim 5 s)$ の 空間分布と卓越領域を示寸破線（同図 4(a)左上）を併せて示す。速 度応答スペクトルの空間分布が大きくなる領域に震源を配置した。 図 3(a)に示した時刻歷波形によると, 震源 A の方位では Radial 成 分が，震源 B の方位では Transverse 成分が他方位よりも大きな振 幅であり，これらの成分についてセンブランス解析を実施すること にした。震源と新宿サイトが入るようにセンブランス解析の領域を 設定して, この領域を $0.8 \mathrm{~km} \times 0.8 \mathrm{~km}$ で分割し, 各グリッドと周 囲の計 9 点を 1 グループとして各グループの伝播方向と速度を計算 した。時間空は 15 秒間とした。波形として周期 3-5 s と周期 5-7 s のバンドパスフィルタを施した 2 ケースを用いた。スナップショッ 卜は，時間空の中心時刻における速度により描画した。

図 10 に，新宿サイトにおけるグリーン関数とその速度振幅が大 きくなる時刻のスナップショットとセンブランス解析で得られた伝 播方向を示寸。震源 $\mathrm{A}$ と B の両方について、それぞれ振幅の大きな 3 区間（A-1 A-3 および B-1 B-3）の結果を示す。図中の矢印の向 きが伝播方向を表す。なお, センブランス值が小さい $\left(S_{0} \leq 0.5\right)$ 結 果はプロットしていない。時刻歴波形には, 震源距離を地震基盤の $V_{P}, V_{S}$ で除して計算した $\mathrm{P}$ 波初動, $\mathrm{S}$ 波初動位置を示した。

各図に共通して, 地震波の波面が震央からの同心円形状ではなく, 歪んだ形状をしている。この波面形状を図 10 に示した震央を中心

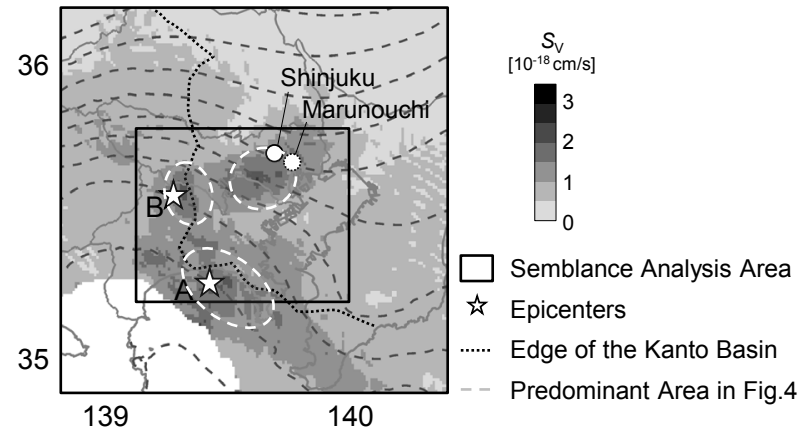

Fig.9 Semblance analysis area and target sources
とする同心円（10 km 刻み）と比較すると, 解析ケース A-2 と B1, B-2 の白破線の領域において, 波面は震源に対して逆向きの円弧 形状になっている。センブランス解析による波の伝播方向から，新 宿と丸の内サイトに向かって波が集中するように伝播する様子が確 認できる。また，その他の解析ケースにおいても，それらの波面が 伝播方向に対して直線上に伸びた波面形状になっており，センブラ ンス解析の結果と併せると，新宿サイトに向かって波線が広がらず に伝播していることが確認できる。波面が広がる場合には伝播距離 に応じた幾何減衰効果が現れるが，上記解析ケースのように波面が 狭まるもしくは広がらない場合には伝播距離に応じた幾何減衰効果 はないか，逆に増幅することとなり，図 10 の新宿サイト周辺でも 波面の性状に対応した大きな振幅の領域が見られる。水平成層地盤 など成形な地盤における波動であれば，震源の放射特性による振幅 の大小はあるが，その波面は震央付近を中心に同心円状に広がって いくが，ここでは関東平野の不整形な地下構造により地震波の伝播 速度が場所により異なり，波面が歪んでいると考えられる。

ここで図 11 に，センブランス解析で得られた新宿サイトにおけ る波動の伝播速度とその直下の 1 次元地下構造モデルから計算され る表面波の分散曲線を比較した。図 11 左には震源 $\mathrm{A} の$ 解析結果と レイリー波の分散曲線を, 右には震源 B の解析結果とラブ波の分散 曲線を示す。センブランス解析に使用したバンドパスフィルタの周 期帯に点線で結果を示す。

図 11 から時刻や周期帯によって異なる種別やモードの波動が卓 越する様子が見られる。具体的には，解析ケース A-1 と A-2, A-3 の新宿サイトの波動はそれぞれ 2 次と 1 次もしくは基本モード，基 本モードのレイリー波, 解析ケース B-1 の波動は 1 次モード, B-2 と B-3 の波動は基本モードのラブ波と対応し周期の分散性が見られ, 振幅が大きくなる区間の波動は表面波と対応寸ると考えられる。

なお，図 10 のスナップショットで新宿サイトと丸の内サイトを 比較すると, 解析ケース B-2 における白破線で囲んだ波群について, 大きな振幅の波群が新宿サイトのわずかに南方を通過し，丸の内サ イトに伝播している。図 12 に, 丸の内サイトの時刻歴波形を示寸。 丸の内サイトでは, 新宿サイトにおける解析ケース B-2 の波動と対 応するものが $75 \mathrm{~s}$ 付近に見られ, その振幅は新宿サイトの 2 倍以上 となっている。このように，新宿サイトと丸の内サイトのように 10 $\mathrm{km}$ 程度の距離しか離れていなくとも, 今回の対象周期 3-5 s では震 動性状が異なる場合があることがわかった。

\section{4. 議論}

本研究では, サイトと震源域を結ぶグリーン関数を建物応答の観 点から可視化して SMGA を配置する方法とその効果を検討するこ とを目的として, 首都圈で発生が危惧される相模卜ラフ沿いのプレ 一ト境界地震を題材に数值シミュレーションを実施した。検討では, 可視化したグリーン関数の空間分布に基づき SMGA を配置した場 合と既往の SMGA 配置による波形合成の結果を比較して，その効 果を確認した。また検討に併せて，グリーン関数が大きくなる震源 領域については, そこから生ずる地震波の伝播経路を推定すること で空間分布の解釈が可能か検討した。

要素震源とサイト間のグリーン関数を震源域に可視化したところ, 東京都心から見て南方から西方の平野端部に沿った領域でグリーン 


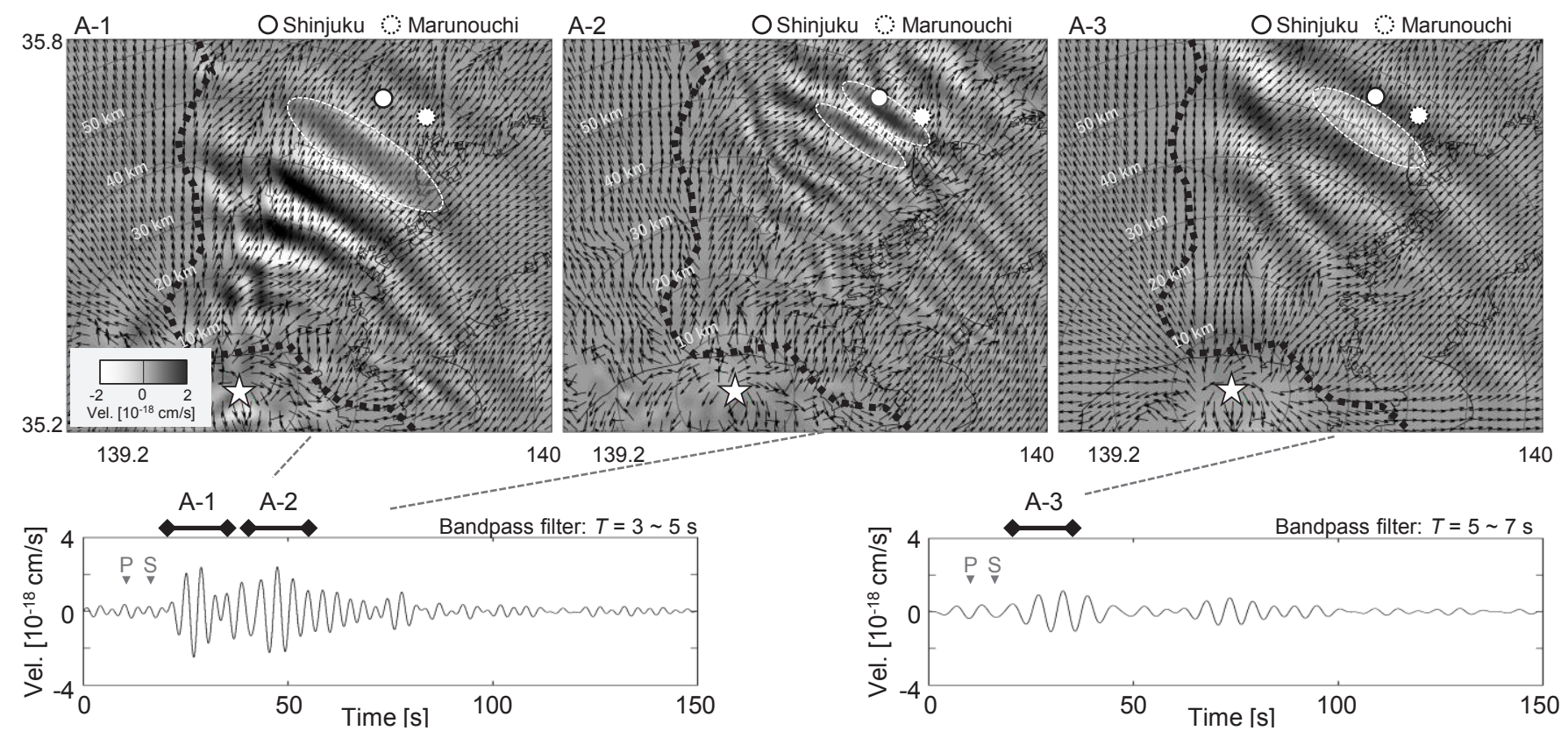

(a) Epicenter A (Radial Component)

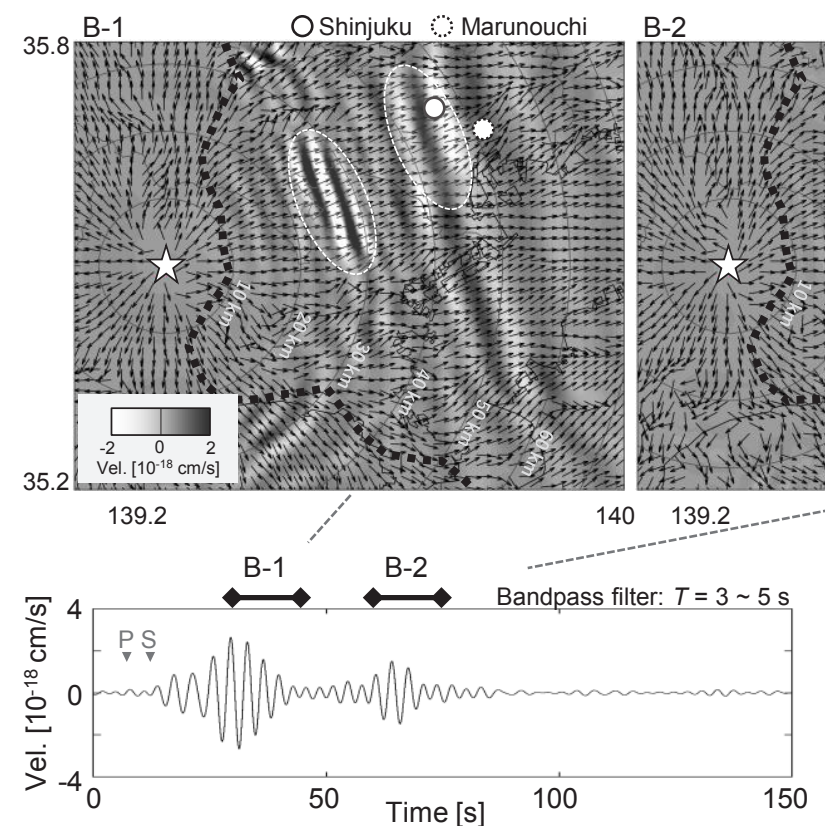

OShinjuku Marunouchi

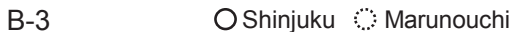

(b) Epicenter B (Transverse Component)

Fig.10 Time history waveform at Shinjuku site and snapshot of the Green's function, propagation direction

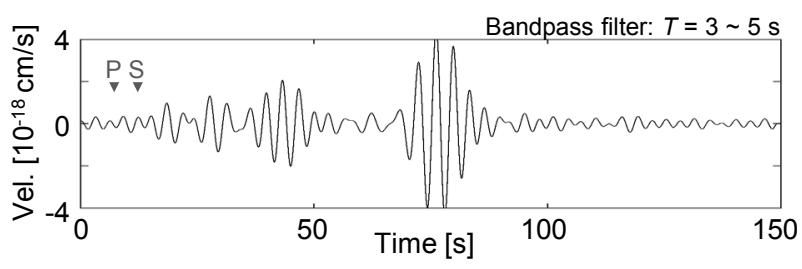

Fig.12 Time history waveform at Marunouchi site
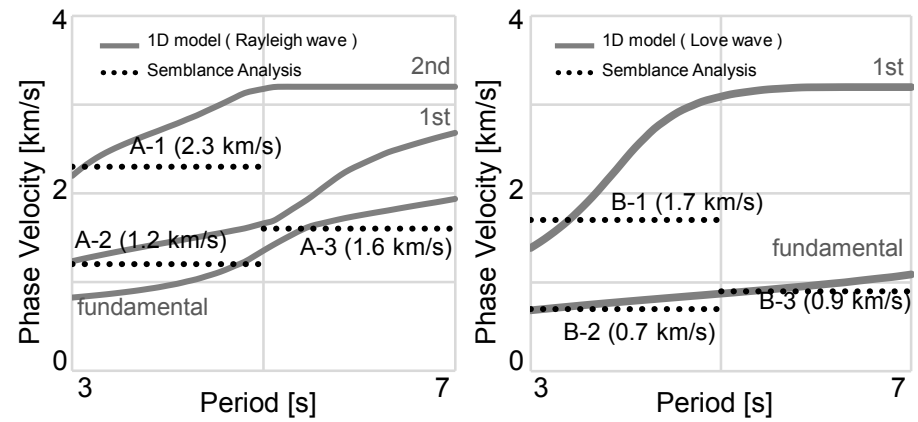

Fig.11 Propagation velocities computed by semblance analysis and based on 1D underground structure 
関数の振幅が大きく, 継続時間が長くなる震源領域が見られた。そ こに SMGA を配置して波形合成を行うと, 従来の計算結果よりも 大きく, 長くなることがわかった。以上から, グリーン関数の応答 スペクトルやエネルギースペクトルの空間分布を可視化し, 応答ス ペクトルやエネルギースペクトルが大きくなる領域に SMGA を配 置することで長周期地震動の震源位置による変動を考慮した地震動 予測ができることがわかった。

ただし，建物周期と減衰定数やサイトを変えた場合のグリーン関 数の空間分布によると, 地震動が大きくなる震源領域がこれらによ り変化することが確認された。すなわち, 対象とする建物の振動特 性や都市ごとにグリーン関数の空間分布を可視化する必要がある。

また, 要素震源のすべり角を変えた場合のグリーン関数の空間分 布によると, 単一の設定值 $\left(140^{\circ}\right)$ の計算結果と複数の設定值 $(0$ ～ $170^{\circ}$ ) の計算結果の最大值について, 地震動が大きくなる震源領 域の方角やおおよその分布が対応しており, 寸べり角による空間分 布の変化は大きくないと考えられる。

次に, センブランス解析により計算波形の伝播経路を推定し, 地 震動が大きくなる震源領域から生ずる地震波は都心部で波線が集中 することを確認した。これまで関東平野周辺で発生した地震につい ては, 既往の研究 10)-13)により関東平野内で波線が合流や集中するこ とは確認されてきたが, 関東平野の直下に位置する海溝型地震につ いても同様の現象がある可能性が示唆された。

本研究の限界は, 上記の検討結果が震源モデルや地下構造モデル の精度に依存することであり, 実現象と完全に一致はしないと考え られる。また, SMGA 以外の破壞開始点やライズタイム, 地震モー メント等の震源パラメータについても検討の余地がある。しかし， 本論の成果を活用寸れば, 実建物の構造設計において使用される数 值解析モデルなどの解析条件の中でより安全側の検討ができるよう になるため, 工学的な意義があると考えられる。具体的には, SMGA 配置の根拠が明確ではない震源断層を想定する場合などに，グリー ン関数の空間分布を参照することで, サイトに影響が大きい SMGA 配置を推定することができる。また，この方法で作成した地震動を 設計に反映しなくとも, 従来の考え方に基づき設定した SMGA 配 置が安全側かどうかを確認する場合にも利用できる。

これまでは過去の震度分布を再現するように設定されたアスペリ ティ位置に基づき SMGA を配置することを基本としており, 震源 モデルが先にある考え方であった。しかし, サイトと建築構造物に とって影響が大きな震源像を把握する本研究のアプローチは, 社会 的に重要度が高い超高層建物や病院, 原子力関係施設などの設計に 活用できる。低層の耐震構造の計画は, 本論文の成果の活用範囲を 超えるが, 免震建物の場合には本論文のアプローチが活用できる。 原子力関係施設の場合は, 本論文で扱った関東平野よりも硬質な地 盤に計画されるものの, 既往の研究 $\left.{ }^{16}\right)$ から震源付近の平野構造も严 イトの地震動に影響を与えることが指摘されており, 計画地周辺の 活断層を対象に, 本論文と同様の検討を実施することで長周期構造 物の安全性をより高められると考える。

今後は, 想定震源域における SMGA の配置から, 拡張して複数の 活断層に対してグリーン関数の空間分布を可視化することで, 影響 が大きな断層やSMGA 配置を選択できるようになると考えている。

\section{5. 結論}

本研究では, サイトと震源域を結ぶグリーン関数を建物応答の観 点から可視化して SMGA を配置する方法とその効果を検討するこ とを目的として, 首都圈で発生が危惧される相模卜ラフ沿いのプレ 一ト境界地震を題材に数值シミュレーションを実施した。

震源域におけるグリーン関数の空間分布は震源距離によらない分 布となっており, 特定の領域でグリーン関数の応答スペクトルやエ ネルギースペクトルが大きくなることを確認した。その領域に SMGA を配置した場合と既往の SMGA 配置による波形合成の結果 を比較したところ, 従来の計算結果よりも振幅が大きく, 継続時間 が長くなる効果を確認した。以上から，グリーン関数の応答スペク トルやエネルギースペクトルの空間分布を可視化し，応答スペクト ルやエネルギースペクトルが大きくなる領域に SMGA を配置する ことで長周期地震動の震源位置による変動を考慮した地震動予測が できることがわかった。

また，題材とした相模トラフ沿いのプレート境界地震と首都圈で の地震動について以下のことがわかった。

・東京都心のサイト（新宿と丸の内）については，サイト南方か ら西方の関東平野端部に沿った震源領域でグリーン関数の振幅 が卓越する。各サイトの直下の震源領域でもグリーン関数の卓越 は見られたが，それと同等以上の振幅であった。

・千葉サイトについては, サイト南方のフィリピン海プレートが 浅い震源領域でグリーン関数が卓越する。

・新宿サイトについて確認されたグリーン関数が卓越する南方か ら西方の震源領域についてセンブランス解析により波動の伝播 経路を推定したところ, サイト周辺で波線が集中しており, これ が卓越の原因であることが確認された。

\section{謝辞}

本研究にあたり，名古屋大学平井敬助教の有限差分法プログラム を使用した。記して感謝の意を表する。

\section{参考文献}

1) Central Disaster Management Council: Nankai Torafu No Kyodai Jishin Moderu Kentoukai (Committee for Evaluating the Rupture Model of Megathrust Earthquakes along the Nankai Trough), 2012.8 (in Japanese), (online), available from

<http://www.bousai.go.jp/jishin/nankai/nankaitrough_info.html>, (accessed 2020-05-03)

中央防災会議 : 南海トラフの巨大地震モデル検討会, 2012.8

2) The Headquarters for Earthquake Research Promotion: Choushuuki Jishindou Hyouka 2016 Nen Shisakuban -Sagami Torafu Kyodai Jishin No Kentou - (Long-Period Ground Motion Evaluation 2016 Trial Version -Examination of the Sagami Trough Megathrust Earthquake-), 2016.10 (in Japanese), (online), available from

<https://www.jishin.go.jp/evaluation/seismic_hazard_map/lpshm/16_ch oshuki/>, (accessed 2020-05-03)

地震調査研究推進本部 : 長周期地震動評価 2016 年試作版一相模卜ラフ巨 大地震の検討一, 2016.10

3) The Headquarters for Earthquake Research Promotion: Strong Ground Motion Prediction Method for Earthquakes with Specified Source Faults ("Recipe"), 2020. 3 (in Japanese), (online), available from $<$ https://www.jishin.go.jp/main/chousa/20_yosokuchizu/recipe.pdf>, (accessed 2020-05-03) 地震調査研究推進本部 : 震源断層を特定した地震の強震動予測手法（「レ シピ」) , 2020.3 
4) Nuclear Regulation Authority: Kijunjishindou Oyobi Taishinsekkei Houshin Nikakawaru Shinsagaido, 2013.6 ( in Japanese), (online), available from <https://www.nsr.go.jp/data/000069160.pdf>, (accessed 2020-11-28)

原子力規制委員会: 基準地震動及び而震設計方針に係る審査ガイド, 2013.6

5) Zama, S.: Characteristics of Long-Period Strong Ground Motion Observed by JMA Strong Motion Seismograph (Part 2: Tokyo), Report of Fire Research institute of Japan, Vol. 76, pp. 1-12, 1993.9 (in Japanese) 座間信作 : 気象庁 1 倍強震計記録にみられるやや長周期地震動特性一その 2 東京一, 消防研究所報告, 第 76 号, pp. 1-12, 1993.9

6) Uetake, T.: Characteristics of Long-Period Ground Motion Around Tokyo Bay Area inferred from Broadband Earthquake Observation (in Japanese), the 13th Japan Earthquake Engineering Symposium, PS2Fri-57, pp. 4157-4164, 2010.11

植竹富一 : 広帯域地震観測に基づく東京湾岸のやや長周期地震動特性, 第 13 回 日本地震工学シンポジウム, PS2-Fri-57, pp. 4157-4164, 2010.11

7) Yuzawa, Y. and Nagumo, H.: Factors of Variability and Measures for the Shakeability of Long-Period Ground Motion - Kanto Basin As An Example -, Journal of Japan Association for Earthquake Engineering, Vol. 12, No.2, pp.41-59, 2012 (in Japanese)

湯沢豊, 南雲秀樹 : 長周期地震動の摇れ易さ係数の変動要因とその低減対 策一関東平野を例として一, 日本地震工学会論文集, 第 12 巻, 第 2 号, pp. 41-59, 2012

8) Ishii, T.: A Study on Response Duration Time Spectra of Earthquake Motions in Tokyo, the 14th World Conference on Earthquake Engineering, Beijing, China, 02-0020, 2008.10

9) Terashima, Y. and Fukuwa, N.: Propagation Characteristics of LongPeriod Ground Motion in the Kanto Plain and Variation Due to Source Location, Journal of Japan Association for Earthquake Engineering, Vol. 19, No.6, pp. 16-35, 2019.10 (in Japanese)

寺島芳洋, 福和伸夫 : 関東平野における長周期地震動の伝播特性と震源位 置による変動, 日本地震工学会論文集, 第 19 巻, 第 6 号, pp.16-35, 2019.10

10) Kato, K., Aki, K. and Teng T.: 3-D Simulations of Surface Wave Propagation in the Kanto Sedimentary Basin, Japan - Part 1: Application of the Surface Wave Gaussian Beam Method, Bulletin of the Seismological Society of America, Vol. 83, No. 6, pp. 1676-1699, 1993.12

11) Hisada, Y., Aki, K. and Teng T.: 3-D Simulations of Surface Wave Propagation in the Kanto Sedimentary Basin, Japan - Part 2: Application of the Surface Wave BEM, Bulletin of the Seismological Society of America, Vol. 83, No. 6, pp. 1700-1720, 1993.12

12) Koketsu, K. and Kikuchi, M.: Propagation of Seismic Ground Motion in the Kanto Basin, Japan, Science, Vol. 288, No. 5469, pp. 1237-1239, 2000.5

13) Furumura, T. and Hayakawa, T.: Anomalous Propagation of LongPeriod Ground Motions Recorded in Tokyo During the 23 October 2004 Mw 6.6 Niigata-Ken Chuetsu, Japan, Earthquake, Bulletin of the Seismological Society of America, Vol. 97, No. 3, pp. 863-880, 2007.6

14) Watanabe, T., Nagano, M., and Kato, K.: Influence of Accretionary Wedge along the Nankai Trough and Earthquake Locations on Longperiod Ground Motions in Tokyo, Journal of Structural and Construction Engineering (Transactions of AIJ), Vol. 79, No. 700, pp. 701-710, 2014.6 (in Japanese)

渡辺哲史, 永野正行, 加藤研一：南海トラフ沿いの付加体および震源位置 が東京の長周期地震動に及ぼす影響, 日本建築学会構造系論文集, 第 79 巻, 第 700 号, pp. 701-710, 2014.6

15) Guo, Y., Koketsu, K. and Miyake, H.: Propagation Mechanism of LongPeriod Ground Motions for Offshore Earthquake along the Nankai Trough: Effects of the Accretionary Wedge, Bulletin of the Seismological Society of America, Vol. 106, No. 3, pp. 1176-1197, 2016.6

16) Yamada, S., Hirai, T. and Fukuwa, N.: The Effect of Sedimentary Basins and Accretionary Wedge on Long Period Ground Motions in Chukyo Area, Journal of Structural and Construction Engineering (Transactions of AIJ), Vol. 82, No. 738, pp. 1165-1175, 2017.8 (in Japanese)

山田沙代, 平井敬, 福和伸夫 : 中京地域で発生する長周期地震動に対する 堆積盆地及び付加体の影響, 日本建築学会構造系論文集, 第 82 巻, 第 738 号，pp. $1165-1175 ， 2017.8$

17) Hirai, T. and Fukuwa, N.: Evaluation Method of Dynamic Characteristics of Sedimentary Basin Using 3-D Finite Difference Method and Reciprocity Theorem, Journal of Structural and Construction Engineering (Transactions of AIJ), Vol. 78, No. 694, pp. 2083-2091, 2013.12 (in Japanese)

平井敬, 福和伸夫 : 3 次元有限差分法と相反定理を用いた堆積盆地の地盤 振動性状の評価手法, 日本建築学会構造系論文集, 第 78 巻, 第 694 号, pp. 2083-2091, 2013.12

18) Petukhin, a. Et Al.: Visualization of Green's Function Anomalies for Megathrust Source in Nankai Trough by Reciprocity Method, Earth Planets and Space, Vol. 68, No.4, 2016.1

19) Terashima, Y. and Fukuwa, N.: Variation Evaluation of Long-Period Ground Motions in the Kanto Plain Due to the Source Location Using the Reciprocity Theorem. Japan Association for Earthquake Engineering Annual Meeting, S21P-06, 2019.9 (in Japanese).

寺島芳洋, 福和伸夫 : 相反定理を用いた関東平野における長周期地震動の 震源方位による変動評価, 日本地震工学会・大会－2019, S21P-06, 2019.9

20) Mukai, Y., Furumura, T., and Maeda, T.: Causes of Azimuthally Dependent Amplification Variations of Long-Period Ground Motions in the Kanto Basin, Central Japan, Bulletin of the Earthquake Research institute, University of Tokyo, Vol. 93, pp. 31-48, 2018 (in Japanese) 向井優理恵・古村孝志・前田拓人 : 関東平野における長周期地震動増幅の 特徵的方位依存性とその要因, 地震研究所彙報, 第 93 巻, pp. 31-48, 2018

21) Tokyo Metropolitan Government: Damage Assumption in Tokyo By an Earthquake Directly Hitting Tokyo, 2012.4 (in Japanese), (online), available from

<https://Www.Bousai.Metro.Tokyo.Lg.Jp/Taisaku/Torikumi/1000902/1 000401.Html>, (accessed 2020-05-03)

東京都：首都直下地震等による東京の被害想定, 2012.4

22) Central Disaster Management Council: Shutocyokkajishin No Higaisoutei To Taisaku Nitsuite (Saishuuhoukoku) (About the Damage Estimation and Countermeasures Concerning the Tokyo inland Earthquake (Final Report)), 2013.12 (in Japanese), (online), available from<http://www.bousai.go.jp/kaigirep/chuobou/senmon/shutochokkajis hinmodel/index.html>, (accessed 2020-05-03) 中央防災会議 : 首都直下地震の被害想定と対策について（最終報告）, 2013.12

23) Koketsu, K. Et Al.: Progress Towards a Japan integrated Velocity Structure Model and Long-Period Ground Motion Hazard Map, the 14th World Conference on Earthquake Engineering, Beijing, China, S10-038, 2008.10

24) Graves, R. W.: Simulating Seismic Wave Propagation in 3D Elastic Media Using Staggered-Grid Finite Differences, Bulletin of the Seismological Society of America, Vol. 86, No. 4, pp. 1091-1106, 1996.8

25) Clayton, R. and Engquist, B.: Absorbing Boundary Conditions for Acoustic and Elastic Wave Equations, Bulletin of the Seismological Society of America, Vol. 67, No. 6, pp. 1529-1540, 1977.12

26) Cerjan, C. Et Al.: A Nonreflecting Boundary Condition for Discrete Acoustic and Elastic Wave Equations, GEOPHYSICS, Vol. 50, No. 4, pp. 705-708, 1985.4

27) Neidell, N. S. and Taner, T.: Semblance and Other Coherency Measures for Multichannel Data, GEOPHYSICS, Vol. 36, No. 3, pp. 467-618, 1971.1

28) Boore, D. M.: Orientation-independent, Nongeometric-Mean Measures of Seismic intensity from Two Horizontal Components of Motion, Bulletin of the Seismological Society of America, Vol. 100, No. 4, pp. 1830-1835, 2010.8

29) Nakamura, H. and Miyatake, T.: An Approximate Expression of Slip Velocity Time Function for Simulation of Near-field Strong Ground Motion, Zisin, Vol.53, No. 1, pp. 1-9, 2000

中村洋光, 宮武隆 : 断層近傍強震動シミュレーションのための滑り速度時 間関数の近似式, 地震 第 2 輯, 第 53 巻, 第 1 号, pp. 1-9, 2000 


\author{
Yoshihiro TERASHIMA *1 and Nobuo Fukuwa ${ }^{* 2}$ \\ ${ }^{11}$ Takenaka Corporation, M.Eng. \\ ${ }^{2}$ Prof., Disaster Mitigation Research Center, Nagoya University, Dr.Eng.
}

\begin{abstract}
When we create input ground motions for building design, it is necessary to consider multiple cases for source parameters such as strong motion generation area (SMGA) arrangement and its area size, and multiple faults. Presently, it is difficult to cover all the possible cases of faults and source parameters. Therefore, we often considered the safety side ground motions with the faults and SMGA placement close to the planned site. However, it has been reported that long-period ground motions do not necessarily directly relate to the distance between the epicenter and the site, and the ground motions vary with the direction of the source and the depth of the hypocenter.
\end{abstract}

The purpose of this study is to examine the arrangement of the SMGAs and to study the effect of the arrangement by visualizing the Green's function between the selected site and the source (hypocenter). This study is conducted by considering the building response to the seismic event. We conducted numerical simulations of the inter-plate earthquake along the Sagami Trough that is anticipated to occur in the Tokyo. In this study, we compared the results of the simulations with various SMGA arrangements. We also examined whether the spatial distribution can be interpreted based on the propagation path of the seismic waves generated from the source area where the Green's functions were large.

From visualizing the Green's function on the source area, the source area with large amplitude and long duration is located along the plain edge from the south to the west from Tokyo. Additionally, it was found that the results of waveform synthesis in case SMGA is arranged at this location, its amplitude becomes larger and duration becomes longer than the conventional calculation results. From the above, by visualizing the spatial distribution of the Green's function and arranging the SMGA to be in the region where these amplitudes are large, it is possible to predict the ground motions considering the variation in the long-period ground motions with source location. However, according to the calculated spatial distribution of the Green's function when the building period, damping constant, and site was changed, the source area that showed a higher Green's function varied. Therefore, it is necessary to visualize the spatial distribution of the Green's function for the buildings with various vibration characteristics in various city.

The limitation of this study is the results depend on the accuracy of the source model and the underground structure model and the results do not completely match the actual ground motions. In addition, there is room to study other source parameters such as the hypocenter (focus), rise time, and seismic moment. However, the present results of this paper can be used to consider the safety side in the structural design of the buildings.

Until now, we have set SMGAs based on the asperity location analyzed from the seismic intensity distribution of the past earthquake. However, this study approach which understand the source parameters that is a major influence the building structure, can be used for the ultimate designing of building and the facilities related to nuclear power that need to consider the maximum class seismic ground motions.

(2020 年 5 月 9 日原稿受理, 2021 年 1 月 18 日採用決定) 